\title{
The supply-side of corruption and limits to preventing corruption within government procurement and constructing ethical subjects
}

\author{
Prem Sikka ${ }^{\mathrm{a}, *}$, Glen Lehman ${ }^{\mathrm{b}}$ \\ ${ }^{a}$ Centre for Global Accountability, University of Essex, UK \\ ${ }^{\mathrm{b}}$ Division of Business, University of South Australia, Australia
}

\section{A R T I C L E I N F O}

\section{Article history:}

Received 25 June 2014

Accepted 1 December 2014

Available online $\mathrm{xxx}$

\section{Keywords:}

Corruption

Government procurement

Internal controls

\begin{abstract}
A B S T R A C T
Corruption in government procurement programs is a perennial problem. The paper by Dean Neu, Jeff Everett and Abu Shiraz Rahaman emphasises the value of internal controls in government departments in constraining individuals and promoting ethical conduct. In response, this paper argues that good internal controls in government departments, though highly desirable, are unlikely to make a significant dent in corrupt practices to secure government contracts. A major reason for this is the supply of corruption by corporations keen to secure lucrative contracts. Within the spirit of contemporary capitalism, they have an insatiable appetite for profits and have shown willingness to engage in corrupt practices to secure government departments. The issues are illustrated with the aid of two case studies. It is argued that the supply-side of corruption severely limits the possibilities of preventing corruption in government procurement.
\end{abstract}

(c) 2015 Elsevier Ltd. All rights reserved.

\section{Introduction}

In a world of secrecy and easy mobility of money, elites seek personal riches, power, status and competitive advantage by renting influence through illicit means. The volume and extent of corrupt activities is hard to know (Serra \& Wantchekon, 2012), but is estimated to be running at around $\$ 2.6$ trillion a year (European Commission, 2011). These amounts are large enough to make a significant difference to economic, social and political policymaking, and the quality of life of citizens. As governments are one of the biggest spenders in any economy, considerable institutional attention is focused on controlling corrupt practices by government officials in granting public contracts (for example, see Organisation for Economic Cooperation and Development, 2005, 2010; United Nations Office on Drugs and Crime, 2003). A common recommendation for reform is enhanced surveillance which "strengthens accountability so that government officials can be held responsible for the proper implementation of public procurement rules and regulations and the decisions they make in actual procurement cases. Such accountability requires a credible sanctioning system for violations of rules with adequate internal controls and audit procedures; a complaints system for bidders as well as appropriate administrative; and judicial review bodies attributed with the authority to impose corrective measures" (European Commission, 2013: 260).

\footnotetext{
We are grateful to John Roberts for his insightful comments.

* Corresponding author at: Centre for Global Accountability, University of Essex, Colchester, Essex CO4 3SQ UK.

E-mail address: prems@essex.ac.uk (P. Sikka).
} 
The above themes are present in the paper by Neu, Everett and Rahaman (2015) which shines a light on the possibility of discouraging and combating corrupt practices within the government procurement process. In Foucaldian traditions, the hope is that ethical subjects/individuals can be produced through suitably designed internal controls and surveillance systems which give visibility to departures from the established norms. Towards this end, government departments are urged to implement and enforce a variety of managerialist techniques and performance indicators, including procedures for risk assessment, training, sanctions, self-reviews and reports by internal and external auditors. The Big Brother approach implicit in the paper presupposes that individuals can be coerced to internalize some value systems and, in the process, somehow become ethical citizens. The surveillance systems advocated by Neu, Everett and Rahaman (2015) portrayed as are universal and are thought to be applicable across almost all cultures regardless of social tensions, legitimacy of the state and networks of power. Internal controls seek to produce a kind of stability and certainty by binding individuals within a system of governance, but they can always be resisted by those able to game or subvert them for personal gain. Some might even comply merely to gain advantage from compliance rather than necessarily embrace the ethical positions envisaged by the paper. The paper's recommendations might constrain some corrupt practices, but the gains are likely to be modest because internal controls aimed at individuals cannot stifle systemic pressures for profits and personal riches.

This paper seeks to extend the debate by Neu, Everett and Rahaman by arguing that public procurement controls, no matter how well designed, are unlikely to significantly reduce corruption in the present social environment. The Neu, Everett and Rahaman paper assumes that government officials indulge in illicit activity and primarily focuses on the demand-side of corruption. However, government officials cannot be corrupt on their own. There is a supply-side and another party has to collude and be willing and able to supply bribes under a cloak of secrecy to secure government contracts (UK Africa All Party Parliamentary Group, 2006). The supply-side primarily resides in large western corporations. George Soros, an international financier adds that "international business is generally the main source of corruption" " and Transparency International adds that "bribe money often stems from multinationals based in the world's richest countries" (Transparency International, 2007: 2). In many cases, the corporations have revenues bigger than the gross domestic product of nation-states, and have access to a vast network of subsidiaries, affiliates and advisers to camouflage their activities. In pursuit of competitive advantage, some corporations and their executives have shown a willingness to subvert laws, international treaties and well designed internal controls instituted in government procurement programs (Boulton, 1979; Chatterjee, 2009). Thus, corruption in government procurement cannot easily be checked without constraints on the supply-side of corruption.

To advance its arguments, this paper is divided into three further sections. The first section explains the supply-side of corruption and pressures that persuade corporations and their executives to engage in corrupt practices. The second section provides two case studies relating to the supply-side of corruption and the tactics used by global corporations to secure government contracts. The first case relates to Hewlett-Packard (HP), a US-based company, selling computer hardware and software to individuals, corporations and government departments. It operates in a market "where it is possible to find a market price for a comparable item" (Neu, Everett, \& Rahaman, 2015: 22) and thus, has benchmarks for checking illicit practices. The second case study relates to BAE Systems plc, a UK-based company, operating in the arms industry, and for "more than a century across the entire globe, the weapons business has been a dirty business" (Naylor, 1998: 35; also see Gilby, 2014). BAE sells high-priced products, often specialized products, where it may be "difficult to determine a market price with the end result that a space is created for corruption to occur” (Neu, Everett, \& Rahaman, 2015: 6). Both companies are headquartered in countries classified as comparatively less corrupt in the Corruption Perceptions Index 2013 published by Transparency International. ${ }^{2}$ The third section concludes the paper with some reflections and suggestions for disrupting the supply of corruption.

\section{Understanding supply-side corruption}

Almost every state prohibits the use of corrupt practices to secure government contracts and considerable efforts have been made to regulate the conduct of government officials associated with the procurement process (Organisation for Economic Cooperation and Development, 2005, 2010; United Nations Office for Drugs and Crime, 2003). Much of the regulatory architecture is devoted to the design of internal controls and surveillance techniques to constrain government officials who are often conceptualized as deviant, greedy, opportunistic and lacking in self-control. The constraints on individuals may curb some who find illicit practices attractive, but also obscure the extent to which institutional structures and norms provide opportunities and motives for corruption. A focus upon government officials obscures the supply-side of corruption which primarily resides in corporations providing goods and services to government departments. Internal controls applicable to government departments can be checked and enforced by state auditors and scrutinized by parliamentary committees. However, the state is largely excluded from directing the inner workings of corporations (Habermas, 1976) and has little power to directly enforce or scrutinize internal controls operating within corporations. The design and implementation of internal controls within corporations is considered to be a private matter for their executives, though the state can exert pressures for higher quality internal controls through laws, threats of fines and punishment for

\footnotetext{
${ }^{1}$ Financial Times, Fund Management Guru Reveals Doubts, 8 December 1998.

2 Corruption Perceptions Index 2013 Available at http://cpi.transparency.org/cpi2013/results/ Accessed 09.06.14.
} 
transgressors, and the debarring of some companies from securing government contracts. Such pressures cannot easily be applied when corporations reside in another country or wield considerable financial and political resources.

Corporations operate according to the logics of competition and private profit. Periodic fines and punishments do not appear to have dulled the appetite for using corrupt practices to secure government contracts (Boulton, 1979; Chatterjee, 2009; Cragg \& Woof, 2002; European Commission, 2013; Passas, 2007; Robins, 2012). Corporations engage in corrupt practices for three major reasons: to maintain higher prices, to maintain a market for outdated products, and to remain in the field of competition, especially if further sales can be secured at a later date (Moody-Stuart, 1997). Corrupt practices may enable corporations to mediate incessant pressures from markets for higher sales, profits and market shares. However, manner of mediation depends on contemporary institutional structures and value systems. Arguably, neoliberalism has been in ascendancy since the second half of twentieth century (Harvey, 2005). It has reconstructed nation states, corporations, communities and individuals as competitive beings engaged in the endless pursuit of private wealth and consumption which would somehow lead to vast increases in efficiency, affluence and happiness. The spirit of neoliberalism is inculcated into every organization and individual through a relentless focus on output measurements of performance, which subjects individuals to a disciplinary regime of surveillance techniques, performance targets, evaluations, appraisals and rewards (Boltanski \& Chiapello, 2005). Such practices normalize the logic of competition and private gain, and performance-related pay has become the norm for business executives. As the typical tenure of a chief executive at a major company is about 4.8 years, ${ }^{3}$ there is a temptation to collect as much reward as quickly as possible. The shortness of the tenure in office means that executives rarely have to face the consequences of any illicit practices, assuming that they are discovered. In any case, the fines, if any, are generally levied on corporations rather than individuals. In this environment, 'bending the rules' for personal gain is increasingly seen as a sign of business acumen. Stealing a march on competitors, at almost any price, is lauded as an entrepreneurial skill, especially where competitive pressures link profits, promotion, niches and salaries with meeting business targets (Sikka, 2008). In the absence of effective moral constraints, any deal is considered to be acceptable as long as it is profitable and shame resides in being caught rather than engaging in corrupt activity. The consequences of such an entrepreneurial culture are noted in a UK government report which states that at some major corporations, directors have a "... cynical disregard of laws and regulations ... cavalier misuse of company monies ... a contempt for truth and common honesty" (UK Department of Trade and Industry, 1997: 309). The above provides the context for understanding the two case studies and reflections on whether internal controls can constrain corporations from using corrupt practices to secure government contracts.

\section{Two case studies}

This section provides brief details of two case studies which show that the lure of private profits and personal gains is not constrained by internal controls. The transactions in the case studies have taken place at a time when there is an extensive regulatory architecture requiring companies to implement effective internal controls and discourage corrupt practices. This includes a variety of laws such as the UK's Fraud Act 2006, Companies Act 2006 and the Bribery Act 2010. The US has the Foreign Corrupt Practices Act 1977 and the Sarbanes-Oxley Act 2002. These laws reflect and have also influenced the 1997 OECD Convention on Combating Bribery of Foreign Public Officials. ${ }^{4}$ In addition, auditing standards in most countries require auditors to evaluate the quality and effectiveness of internal controls (for example, Financial Reporting Council, 1995). These requirements should focus executive attention on the need for legal and ethical conduct, but too many corporations have been cited for their participation in corrupt practices (Cragg \& Woof, 2002).

\subsection{Hewlett-Packard}

HP operates from 770 sites in 95 countries. ${ }^{5}$ In April 2014, the company paid a fine of $\$ 108$ million for violation of the US Foreign Corrupt Practices Act. ${ }^{6}$ The charges related to the payment of bribes to secure government contracts in Russia, Poland and Mexico. ${ }^{7}$ The court judgment provides some details of the practices and encourages reflections on the extent of corporate practices used to pursue profits (US Securities and Exchange Commission, 2014).

During the period 2000-2007, the Russian subsidiary of HP (hereafter HP Russia) paid bribes through agents and consultants to government officials in Russia to secure contracts for computer hardware and software worth an estimated $€ 35$ million (\$42 million). HP Russia was keen to secure this contract with the Office of the Prosecutor of General of Russia because it was seen as a 'golden key' for unlocking further contracts of around $\$ 100$ million (US Securities and Exchange

\footnotetext{
${ }^{3}$ The Daily Telegraph, 'CEOs must keep learning to avoid the five-year axe', http://www.telegraph.co.uk/finance/businessclub/management-advice/ 10064862/CEOs-must-keep-learning-to-avoid-the-five-year-axe.html Accessed 03.06.14.

${ }^{4}$ For some details see http://www.business-anti-corruption.com/about/about-corruption/the-oecd-convention-on-combating-bribery-offoreign-public-officials-in-international-business-transactions.aspx.

${ }^{5}$ As per http://www.hp.com/hpinfo/globalcitizenship/media/files/hp_fy11_gcr_hp_operations.pdf Accessed 18.05.14.

${ }^{6}$ US Securities and Exchange Commission press release, SEC Charges Hewlett-Packard With FCPA Violations, 9 April 2014 (http://www.sec.gov/News/ PressRelease/Detail/PressRelease/1370541453075\# U6GC6FRwaic Accessed 18.05.14).

7 US Justice Department press release, Hewlett-Packard Russia Agrees to Plead Guilty to Foreign Bribery, 9 April 2014 (http://www.justice.gov/opa/pr/ 2014/April/14-crm-358.html Accessed 17.05.14)
} 
Commission, 2014: 3). To secure the contract, HP Russia created a secret slush fund to facilitate bribes to government officials directly, as well as through agents and intermediaries. HP Russia created excess profit margins for the slush fund through an elaborate buy-back deal structure (US Department of Justice, 2014), whereby (1) HP sold the computer hardware and other technology products called for under the contract to a Russian channel partner, (2) HP bought the same products back from an intermediary company at a nearly $€ 8$ million mark-up and paid the intermediary an additional $€ 4.2$ million for purported services, and (3) HP sold the same products to the Russian government at the increased price. The payments to the intermediary were made through a series of shell companies, some of which were directly associated with government officials, registered in the US, the UK, the British Virgin Islands and Belize. Some monies were laundered through offshore bank accounts in Switzerland, Lithuania, Latvia and Austria. Portions of the funds were spent on travel, cars, jewelry, clothing, expensive watches, swimming pool technology, furniture, household appliances and other luxury goods for government officials. To conceal the corrupt payment, HP Russia employees kept two sets of books (US Securities and Exchange Commission, 2014: 5): (i) an internal set of documents that identified the recipients of the payments, and (ii) a sanitized version of the same documents that were provided to management in the credit, finance, and legal offices outside of HP Russia. There were also off-the-books side agreements. As one example, an HP Russia executive executed a letter agreement to pay $€ 2.8$ million in purported "commission" fees to a UK-registered shell company which was linked to a director of the Russian government agency responsible for managing the project. HP Russia did not disclose the existence of the agreement to internal or external auditors or management outside of HP Russia. At one stage, HP Russia's country manager signed a contract which was being handled by an HP subsidiary in Germany even though he had no authority, or power of attorney, to act on behalf of the German subsidiary. When, three months later, the German subsidiary learnt of this, it ratified the contract through a retroactive power of attorney. HP Russia made about \$10.4 million in illicit profits from its Russian contract (US Securities and Exchange Commission, 2014: 5).

The tactic of bribing government officials to secure contracts was also used in Poland (US Securities and Exchange Commission, 2014). US court documents show that between 2006 and 2010, HP Poland made improper payments to one or more government officials to secure and maintain lucrative government contracts with the Polish national police agency. HP Poland's employees, including senior officials, circumvented internal controls to provide free laptop and desktop computers, iPods, flat screen televisions, cameras, home theater systems, dinners, flights and sightseeing tours to government officials. Many of these were paid in cash, without authorization, and were not properly recorded in HP's books and accounts. After some initial lucrative contracts, HP Poland employees and agents expanded the bribes to include large cash payments from off-book accounts and the government officials were promised $1.2 \%$ of net revenue from the relevant contracts. When, in March 2007, a Polish official signed a contract valued at $\$ 15.8$ million, a bag containing $\$ 150,000$ in cash was left at his home. A further $\$ 100,000$ in cash was handed over in a Warsaw parking lot, followed by further cash payments of $\$ 360,000$. The relationship was also cultivated through covert means. In one method, a HP Poland executive established multiple anonymous e-mail accounts and shared the passwords with the Polish IT Official so that he could write and save messages as "drafts" within the account. The HP Poland executive also provided the Polish government official with prepaid mobile telephones. The HP Poland executive and the government official also met in remote locations where they would communicate silently by typing information on a laptop computer about upcoming tenders and bribes. Through corrupt means, HP Poland secured contracts worth approximately $\$ 60$ million and generated profits of about $\$ 16.1$ million.

The tendency to secure government contracts through illicit payments is also encountered in Mexico (US Securities and Exchange Commission, 2014). Here hardware, software and licensing contracts worth \$6 million were sought with Mexico’s state-owned petroleum company, Petroleos Mexico. Once again, agents were cultivated and paid secret fees, this time called "influencer fee". This was equivalent to $25 \%$ of the licensing and support components of the deal. There was no written agreement with the agent selected and the amounts were passed through shell companies and records were falsified. HP Mexico made $\$ 2.5$ million profit from the deals.

Commenting on the $\$ 108$ million fine for HP, a spokesperson for the Securities and Exchange Commission enforcement division said that "Hewlett-Packard lacked the internal controls to stop a pattern of illegal payments to win business in Mexico and Eastern Europe. The company's books and records reflected the payments as legitimate commissions and expenses. Companies have a fundamental obligation to ensure that their internal controls are both reasonably designed and appropriately implemented across their entire business operations, and they should take a hard look at the agents conducting business on their behalf'. ${ }^{8}$ Ernst \& Young were the global auditors of HP throughout the period during which corrupt payments were made. The company always received unqualified audit opinion.

\subsection{BAE Systems plc}

BAE Systems plc $^{9}$ (BAES) is the world's second largest defence contractor. It exports a wide range of products and services for air, land and naval forces, as well as advanced electronics, security, information technology and support services. It has customers in over 100 countries, though most of its business is based around four key markets - the US, the UK, the Kingdom

\footnotetext{
8 The Guardian, Hewlett-Packard to pay \$108 m to settle scandal over bribery of public officials, 9 April 2014 (http://www.theguardian.com/business/ 2014/apr/09/hewlett-packard-108m-corruption-government-it-us-bribery Accessed 15.06.14).

${ }^{9}$ It is the successor company formed in 1999 after the merger of British Aerospace and Marconi Electronic System.
} 
of Saudi Arabia and Australia. ${ }^{10}$ The company's sales have been the subject of critical media scrutiny for some time. For example, The Guardian newspaper has claimed that “Three huge BAE deals with the Saudi royal family kept Britain's sole warplane manufacturer in profitable existence in the 1960s and 70s. All were corrupt ... successive UK governments, desperate for foreign exchange, took no notice". ${ }^{11}$ In 1985, the UK and Saudi governments signed a government-togovernment contract ${ }^{12}$ known as the $\mathrm{Al}$ Yamamah contract. The $£ 43$ billion contract was Britain's biggest ever arms export deal and BAE Systems would provide Tornado and Hawk jets and other military equipment. It was soon alleged that the Prime Minister's son, Mark Thatcher, received kickbacks for the contract. ${ }^{13}$ In 1989, amidst allegations of the payment of secret commissions to a number of agents and Saudi royals, the National Audit Office ${ }^{14}$ (NAO) began an investigation. ${ }^{15}$ In 1992, the investigation was abruptly discontinued and the report remains unpublished "amidst fears that its publication would offend the notoriously sensitive Saudis, jeopardizing continuing trade relations". ${ }^{16}$ In 2004, it was reported that BAE's chief operating officer operated a "slush fund" which made corrupt payments of $£ 60$ million to Saudi officials, including providing prostitutes, Rolls-Royces and Californian holidays. ${ }^{17}$ The company allegedly used an elaborate process of false accounting to make and conceal payments through shell companies. Some of the entries were in code in order to conceal the identity of the recipients. BAE's response to allegations was a response that it "can state categorically that there is not now and there has never been in existence what the media refers to as a 'slush fund'. Neither has BAE Systems or any of its officers or employees been involved in false accounting". ${ }^{18}$

The media revelations, accompanied by documentary evidence, persuaded the Serious Fraud Office ${ }^{19}$ (SFO) to launch an investigation. On 1st December 2006, it was reported that "Saudi Arabia has given Britain 10 days to halt a fraud investigation into the country's arms trade ... The country's advisers have made clear through diplomatic channels that unless the inquiry is closed, the kingdom's arms business will be taken elsewhere". ${ }^{20}$ In 14 December 2006, the Attorney General told parliament that the investigation had been abandoned because of the "need to safeguard national and international security. It has been necessary to balance the need to maintain the rule of law against the wider public interest". ${ }^{21}$ Prime Minister Tony Blair defended the action by saying that "the result would have been devastating for our relationship with an important country". ${ }^{22}$ The US authorities, ${ }^{23}$ which had launched an investigation in 2005, were not pleased $^{24}$ and made a formal protest to the UK government.

Attention was now focused on the US investigation into BAE Systems Inc., the US subsidiary of BAE System plc, for its role in the Saudi arms deal, as well as contracts for supplies to South Africa, Chile, the Czech Republic, Romania, Tanzania and Qatar. On 1st March 2010, the US Department of Justice announced that BAE Systems plc had pleaded guilty to conspiring to defraud the United States by impairing and impeding its lawful functions and making false statements about its Foreign Corrupt Practices Act compliance program, and violating the Arms Export Control Act and International Traffic in Arms Regulations. BAE was ordered to pay a $\$ 400$ million criminal fine. ${ }^{25}$ The court order (United States District Court for the District of Columbia, 2010) relating to sales in Saudi Arabia, Hungary and the Czech Republic stated that "BAES knowingly and willfully failed to identify commissions paid to third parties for assistance in the solicitation or promotion or otherwise to secure the conclusion of the sale of defense articles ..." (p. 6). In the company's records, the middlemen were described as "marketing advisers" and BAES took active steps to conceal its relationships with them. BAES used onshore and offshore shell

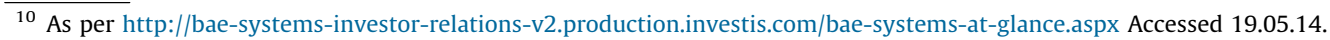

${ }^{11}$ As per http://www.theguardian.com/baefiles/page/0,2095814,00.html Accessed 21.05.14.

12 In legal terms, this means that BAE sold equipment to the UK government, which then sold it to the government of Saudi Arabia. As the sale is technically by the government, this entitles UK government auditors (e.g. the National Audit Office) to scrutinize the process.

13 The Independent, Mark Thatcher accused: Sources say he got $12 \mathrm{~m}$ pounds from arms deal signed by his mother, 9 October 1004 (http://www. independent.co.uk/news/mark-thatcher-accused-sources-say-he-got-12m-pounds-from-arms-deal-signed-by-his-mother-1441851.html Accessed 20.05.14).

${ }^{14}$ It is a Parliamentary body independent of any UK government departments which scrutinizes public spending by government departments, government agencies and non-government pubic bodies.

${ }_{15}$ The Daily Telegraph, BAE's arms deals with Saudi Arabia: Timeline, 30 July 2008 (http://www.telegraph.co.uk/news/worldnews/middleeast/ saudiarabia/2473238/BAEs-arms-deals-with-Saudi-Arabia-Timeline.html Accessed 25.05.14).

${ }^{16}$ The Daily Telegraph, SFO illegally dropped Saudi arms inquiry, judge rules, 10 April 2008 (http://www.telegraph.co.uk/news/uknews/1584595/ SFO-illegally-dropped-Saudi-arms-inquiry-judge-rules.html Accessed 23.05.14).

17 The Guardian, BAE chief linked to slush fund, 5 October 2004 (http://www.theguardian.com/uk/2004/oct/05/saudiarabia.armstrade Accessed 24.05.14).

${ }^{18}$ BBC News, BBC lifts the lid on secret BAE slush fund, 5 October 2004 (http://news.bbc.co.uk/1/hi/business/3712770.stm Accessed 19.11.14).

19 SFO is a government department charged with investigation and prosecution of serious or complex fraud, and corruption.

${ }^{20}$ The Daily Telegraph, Halt inquiry or we cancel Eurofighters, 1 December 2006 (http://www.telegraph.co.uk/news/uknews/1535683/ Halt-inquiry-or-we-cancel-Eurofighters.html Accessed 20.05.14).

${ }^{21}$ Hansard, House of Lords Debates, 14 December 2006, col. 1712 (http://www.publications.parliament.uk/pa/ld200607/ldhansrd/text/61214-0014.htm Accessed 01.06.14).

22 The Guardian, Dropping BAE inquiry vital to national interest, says Blair, 16 January 2007 (http://www.theguardian.com/world/2007/jan/16/bae. immigrationpolicy Accessed 01.06.14).

${ }^{23}$ Financial Times, US issued protest on axing of BAE probe, 27 April 2007 (http://www.ft.com/cms/s/0/b008fd02-f45c-11db-88aa-000b5df10621. html\#axzz355ZUUp36 Accessed 01.06.14).

${ }^{24}$ UK NGOs made attempts to force the government to continue with its investigations, but were ultimately unsuccessful (The Guardian, Lords rule SFO was lawful in halting BAE arms corruption inquiry, 30 July 2008; http://www.theguardian.com/world/2008/jul/30/bae.armstrade Accessed 30.05.14).

${ }^{25}$ US Department of Justice press release, BAE Systems PLC Pleads Guilty and Ordered to Pay \$400 Million Criminal Fine, 1 March 2010 (http://www. justice.gov/opa/pr/2010/March/10-crm-209.html Accessed 03.06.14).
} 
companies to disguise the origins of secret commissions and also advised recipients to use offshore shell companies. There was little internal scrutiny of the payments. The court order noted that "BAES established one entity in the British Virgin Islands to conceal BAES's marketing advisor relationships, including who the agent was and how much it was paid; to create obstacles for investigating authorities to penetrate the arrangements; to circumvent laws in countries that did not allow agency relationships; and to assist advisors in avoiding tax liability for payments from BAES" (p. 8). BAES's official records maintained inadequate information about the identity of the advisors and the nature of their work and, frequently the communication was not in writing. Between May and November 2001 alone, BAES made payments of over $£ 135,000,000$ (about $\$ 216$ million) and over $\$ 14,000,000$ to certain of its marketing advisors and agents through offshore entities. (p. 9). There is little persuasive evidence to show that the advisers performed legitimate activities to justify the receipt of substantial payments. Amongst other things, the court order noted that for the Saudi contract, BAES provided substantial benefits to one public official and his associates (p. 12). These included "sums totaling more than $£ 10,000,000$ and more than $\$ 9,000,000$ to a bank account in Switzerland controlled by an intermediary" (p. 13). For the contract to supply Grippen fighter planes to the Czech Republic and Hungary, BAES made payments of more than $£ 19,000,000$ to entities associated with an unnamed agent. BAES made "these payments even though there was a high probability that part of the payments would be used in the tender process to favor BAES" (p. 9-10). In May 2011, the US government levied another fine of $\$ 79$ million on BAE for violation of defense export controls ${ }^{26}$ for the period 1997-2010 (United States Department of State, 2011).

In December 2010, the UK authorities announced that BAE had agreed to make an ex-gratia payment of $£ 29.5$ million to the Tanzanian government, which the company's 2011 annual report referred to as a "charitable contribution ${ }^{27}$ " to be used for educating children in Tanzania. ${ }^{28}$ A fine of $£ 500,000$ was negotiated by the UK authorities for failing to "keep adequate accounting records ${ }^{29}$ in relation to a defence contract for the supply of an air traffic control system to the Government of Tanzania". ${ }^{30}$ The background is that, in 1999, BAE, with the support of the UK government, entered into an agreement with the Tanzanian government to supply an air traffic control system at the price of about $\$ 40$ million ( $£ 28$ million). The UK government helped to secure the finance from Barclays Bank. ${ }^{31}$ The World Bank and the International Monetary Fund opposed the deal by arguing that an effective radar system should only cost about $\$ 10$ million $^{32}$ (f7 million). The UK court order ${ }^{33}$ for the fine provides some details of the discrepancies. Some $\$ 12.4$ million (30\% of the contract value) ended up in two offshore companies operated by an agent. The payments were recorded in accounting records by BAE as payments for the provision of technical services by the agent. The court documentation noted that "there was a high probability that part of the $\$ 12.4$ million would be used in the negotiation process to favor British Aerospace Defence Systems Ltd. The payments were not subjected to proper or adequate scrutiny or review" (para 4.5). The failure to record the information accurately was the result of a deliberate decision by officials. Despite the admission that the company had failed to keep adequate accounting records, its annual financial statements continued to receive unqualified audit opinions. The judge expressed his surprise that the UK's law enforcement officers had given BAE officials blanket immunities from any future prosecutions.

In October 2010, the UK's accounting regulator, the Financial Reporting Council, announced that it would investigate audits and professional services advice provided by KPMG to BAE in the period 1997-2007, but in 2013, the investigation was abruptly abandoned because "proper assessment of KPMG's conduct would require consideration of work undertaken in earlier years. Because there is no realistic prospect that a Tribunal will make an adverse finding in respect of a complaint relating to work done so long ago it has been concluded that it is not in the public interest to extend the investigation to the years preceding 1997". ${ }^{34}$

\section{Summary and discussion}

It may be possible to design internal controls systems that enhance possibilities of combating corrupt practices within the government procurement process. However, government departments transact with private sector corporations who compete to secure government contracts. Corporations are under incessant pressure from markets and shareholders for

\footnotetext{
${ }^{26}$ Also see Wall Street Journal, BAE Pays \$79 Million To Settle Case With State Department, 17 May 2011(http://blogs.wsj.com/corruption-currents/2011/ 05/17/bae-pays-79-million-to-settle-case-with-state-department/ Accessed 22.06.14).

27 Page 49 of the 2011 annual report, Available at http://bae-systems-investor-relations-v2.production.investis.com/ /media/Files/B/ BAE-Systems-Investor-Relations-V2/PDFs/results-and-reports/reports/2012a/ar-2011.pdf Accessed 20.06.14.

28 Serious Fraud Office press release, BAE Systems will pay toward educating children in Tanzania after signing an agreement brokered by the Serious Fraud Office, 15 March 2012 (http://www.sfo.gov.uk/press-room/latest-press-releases/press-releases-2012/bae-systems-will-pay-towards-educating-childrenin-tanzania-after-signing-an-agreement-brokered-by-the-serious-fraud-office.aspx Accessed 17.06.14).

${ }^{29}$ This was a statutory requirement under Section 221 of the Companies Act 1985.

${ }^{30}$ Serious Fraud Office press release, BAE fined in Tanzania defence contract case, 21 December 2010 (http://www.sfo.gov.uk/press-room/ press-release-archive/press-releases-2010/bae-fined-in-tanzania-defence-contract-case.aspx Accessed 02.06.14).

31 Hansard, House of Commons Debates, 25 June 2002, cols. 228-236.

32 BBC News, World Bank hits out at Tanzania deal, 22 December 2001 (http://news.bbc.co.uk/1/hi/uk_politics/1723296.stm Accessed 23.05.14).

${ }^{33} \mathrm{R}$ and BAE Systems PLC [2010] EW Misc 16 (CC) (21 December 2010) Available at http://www.bailii.org/ew/cases/Misc/2010/16.pdf Accessed 03.06.14

${ }^{34}$ Financial Reporting Council press release, Closure of investigation into the conduct of: KPMG Audit plc, Member Firm of the ICAEW, 1 August 2013; https://www.frc.org.uk/News-and-Events/FRC-Press/Press/2013/August/Closure-of-investigation-into-the-conduct-of-KPMG.aspx Accessed 31.05.14).
} 
higher profits and have to distinguish themselves from their competitors. One way of stealing a march on competitors is by using illicit means to secure sales to government departments. Following the 1997 OECD Convention on Combating Bribery of Foreign Public Officials and the US Foreign Corrupt Practices Act 1977, corporate executives should be aware of their obligations and possible retribution for bribing government officials to secure contracts, but they still indulge in corrupt practices. The two case studies presented in this paper show that corporations went to enormous lengths to bribe individuals to secure contracts. Some employees may have resisted illicit practices, but corporate officials used clandestine meetings, bags full of cash, agents, shell companies and false accounting to pursue corporate interests. These were not the actions of some isolated individuals, but seem to be deliberate policies crafted at senior levels. No executive has been fined, imprisoned, or forced to return the personal gains made from corrupt practices. The supply of corruption is so deeply ingrained into corporate governance structures that some companies even employ private detectives to recover bribes if the recipients fail to deliver the promised benefits (Hawley, 2000).

Following Neu, Everett and Rahaman (2015) arguments, it may be possible to use market prices as benchmarks to detect artificial and inflated prices, but the case studies suggest that this process may not work smoothly. Major corporations dominate markets, and have considerable discretion in setting prices, especially if markets are fragmented, or compartmentalized into geographical jurisdictions (Sikka \& Willmott, 2010). HP deployed an elaborate scheme to inflate market prices for computer hardware and software. The creation of artificial prices requires collusion between the buyer and the seller. The buyer was subject to internal controls instituted by government departments, whilst the seller was driven by the logic of private profits. HP's books and internal controls could not be inspected by the governments of Russia, Poland and Mexico. In any case, the accounting records could not easily distinguish between the normal and illicit practices. In the case of the Tanzanian contract, BAE priced its radar system at \$40 million against an expected price of around $\$ 10$ million. Despite this discrepancy, the sale went ahead with the full support of the UK government, and corrupt practices were not checked.

None of the corrupt practices highlighted in this paper were brought to the attention of the public or regulators by internal or external auditors of the companies even though they are central to debates about controlling corruption in government procurement. Both HP and BAE bolstered internal checks and balances with audit committees and nonexecutive directors, but they do not appear to have been effective in curtailing or exposing corrupt practices. Even if suitable internal controls could be devised to combat both the demand and supply of corruption, they are most likely to constrain selected individuals. They cannot easily make a serious dent in the systemic origins of corrupt practices which are embedded in the spirit of contemporary capitalism that celebrates competition, individualization and quest for personal riches.

Government auditors and law enforcement agencies may have the capacity to check corrupt practices, but the reality is murkier. In the case of BAE, the UK state went to considerable length to thwart investigations. The NAO, the government auditor, was prevented from investigating the frauds. In pursuit of what the government called "national" interests, the SFO, a law enforcement agency, was neutered. The UK government granted immunities to BAE officials from future investigations and prosecutions. Seemingly, the commercial interests of BAE and its capacity to export arms took priority over attempts to combat corruption. There is something very troubling for democratic sensibilities in that the UK government's interventions to prevent investigations of corrupt practices were accompanied by the claims that the rule of law is not compatible with pursuit of the public interest and exposure of corrupt practices. Such worldviews pose serious questions about the willingness of western states to eradicate the supply of corruption.

There is mounting evidence that internal controls are probably not constraining corporate participation in predatory practices (for example, see Hadden et al., 2014; Mitchell \& Sikka, 2011). Interestingly, the controls and disciplinary practices are mobilized to enact a theater of legality and probity. In the case of HP, its 2013 financial statements identified some of the on-going litigation and investigations under the heading of 'litigation and contingencies', but with minimal detail. The word “bribery" appeared only three times in a 180 page document. The company's 2013 'Living Progress Report' (its corporate social responsibility report) stated that "HP does not tolerate corrupt behavior and prohibits bribery or kickbacks in any circumstance. Corrupt behavior is an impediment to social and economic development. It undermines the values on which $\mathrm{HP}$ is built, the principles of fair competition, and the rule of law". ${ }^{35}$ BAE response was interesting. In 2007, it appointed a committee of grandees, chaired by Lord Woolf of Barnes, former Lord Chief Justice of England and Wales. The eventual report (Woolf Committee, 2008) provided a brief glimpse of the already publicly known allegations, but was accompanied by denial. The report said that the "Company has always maintained that it does not believe that it has done anything that would constitute a criminal offense ... [and that the payments] "were lawful commissions and not secret payments" (Woolf Committee, 2008: 8). The report made 23 recommendations for the company to improve ethical practices, something that has become a resource for the company in reassuring its critics, ${ }^{36}$ especially after the fines imposed by the US government. The recommendations, such as those relating to staff training, adherence to ethical codes, a new code of government lobbying, enhanced role for internal audit, a register for gifts and hospitality and linking of executive remuneration to ethical practices etc., reinforce disciplinary technologies and also create possibilities for finding scapegoats in future episodes. This

\footnotetext{
35 HP2013Living Progress Report, p. 22 (http://h20195.www2.hp.com/V2/GetPDF.aspx/c04152740.pdf Accessed 15.06.14).

36 For example, see “Governance Summary" in the BAE's 2013 annual report on page 64 (http://bae-systems-investor-relations-v2.production.investis. com/ /media/Files/B/BAE-Systems-Investor-Relations-V2/Annual\%20Reports/BAE-annual-report-2013.pdf Accessed 20.11.14).
} 
disciplinary apparatus may facilitate the production of ethical individuals envisaged by Neu, Everett and Rahaman, but cannot easily check the supply-side of corruption.

The central message of this paper is that there are limits to the effectiveness of internal controls in government procurement programs. The controls can be undermined not only by strategically placed officials from within, but by the constant attacks from private sector corporations transacting with the government departments. So what can be done to control the supply-side corruption? Perhaps the offending companies, in this case HP and BAE could be debarred for a long period from securing any government contracts, but in the face of strong corporate lobbying, such laws are unlikely to emerge. Their executives could be personally fined and extradited to the countries suffering from corrupt practices, but such international laws and treaties either do not exist or are weak. To prevent a country like the UK from delaying, obfuscating and abandoning investigations, there should be joint investigations involving the supply-side and demand-side countries. Following the examples in case studies this could have been a joint investigation involving the US, Russia Poland and Mexico, or the UK, Saudi Arabia and Tanzania. However, even that runs into difficulties, as some countries (Saudi Arabia) were not keen on any investigation. Some of the proceeds of corruption pass through offshore places facilitating secrecy and they are unlikely to cooperate fully. In any case, various states would probably bring their national interests to bear on any investigation, with the fight against corruption taking a back seat. Evidently, much needs to be done to control supply-side corruption.

The persistence of corruption highlights a failure of education at home, work, school, university and society. There is an urgent need for a program of deschooling (Illich, 1974) so that corporate executives can recognize their contribution to social problems. Corporations need to accept that they were created to serve society and must have legal responsibilities wider than the simple pursuit of private profits. Their records need to be publicly accessible so that all citizens can evaluate their activities and call them to account. Individuals need to be detoxified from the neoliberal obsession with accumulation of wealth, power and status. Without this, programs of surveillance and internal controls may achieve marginal success, but are unlikely to make a significant dent in curbing corrupt practices.

There is also an urgent need for further research into socialization of individuals into corporate culture which incubates corrupt practices. The accounts of 'insiders' (Perkins, 2004) can do much to illuminate contradictions of organizational practices which are frequently designed to present a legitimate face to the outside world whilst internal dynamics are engaged in headlong rush for private profits, at almost any cost.

\section{References}

Boltanski, L., \& Chiapello, E. (2005). The new spirit of capitalism. London: Verso.

Boulton, D. (1979). The grease machine - The inside story of Lockheed's dollar diplomacy. New York: Harper \& Row.

Chatterjee, P. (2009). Halliburton's army: How a well-connected Texas oil company revolutionized the way America makes war. New York: Nation Books.

Cragg, W. A., \& Woof, W. (2002). The US Foreign Corrupt Practices Act and its implications for the control of corruption in political life. Business \&' Society Review, 107(1), 98-144.

European Commission (2011). Working paper: On establishing an EU anti-corruption reporting mechanism for periodic assessment. Brussels: European Commission ("EU Anti-Corruption Report"), Brussels: EU (http://ec.europa.eu/smart-regulation/impact/ia_carried_out/docs/ia_2011/sec_2011_0661_en.pdf).

European Commission (2013). Identifying and Reducing Corruption in Public Procurement in the EU. Brussels: European Commission http://ec.europa.eu/anti_fraud/ documents/anti-fraud-policy/research-and-studies/identifying reducing corruption in public procurement en.pdf

Financial Reporting Council (1995). SAS 300: Accounting and internal control systems and risk assessments. London: FRC.

Gilby, N. (2014). Deception in high places: A history of bribery in Britain's arms trade. London: Pluto.

Habermas, J. (1976). Legitimation crisis. London: Heinemann.

Hadden, T., Ireland, P., Morgan, G., Parker, M., Pearson, G., Picciotto, S., et al. (2014). Fighting corporate abuse: Beyond predatory capitalism. London: Pluto.

Harvey, D. (2005). A brief history of neoliberalism. Oxford: Oxford University Press.

Hawley, S. (2000). Corner House briefing 19: Exporting corruption privatisation, multinationals and bribery. Sturminster Newton: The Corner House http://www. thecornerhouse.org.uk/sites/thecornerhouse.org.uk/files/19bribe_0.pdf

Illich, I. (1974). Deschooling society. London: Penguin.

Mitchell, A., \& Sikka, P. (2011). The pin-stripe mafia: How accountancy firms destroy societies. Basildon: Association for Accountancy \& Business Affairs.

Moody-Stuart, G. (1997). Grand corruption: How business bribes damage developing countries. Oxford: WorldView Publishing.

Naylor, T. (1998). Corruption in modern arms business: Lessons from the Pentagon scandals. In A. K. Jain (Ed.), Economics of corruption. Norwell: Kluwer.

Neu, D., Everett, J., \& Rahaman, A. S. (2015). Preventing corruption within government procurement: Constructing the disciplined and ethical subject. Critical Perspectives on Accounting. http://dx.doi.org/10.1016/j.cpa.2015.01.007 (in press)

Organisation for Economic Cooperation and Development (2005). Public procurement in OECD, fighting corruption and promoting integrity in public procurement. Paris: OECD.

Organisation for Economic Cooperation and Development (2010). Collusion and corruption in public procurement. Paris: OECD.

Passas, N. (2007). Corruption in the procurement process/outsourcing government functions: Issues, cases studies, implication. Boston: Institute for Fraud Prevention. Perkins, J. (2004). Confessions of an economic hit man. San Francisco: Berrett-Koehler.

Robins, N. (2012). The corporation that changed the world: How the East India company shaped the modern multinational. London: Pluto.

Serra, D., \& Wantchekon, L. (2012). New advances in experimental research on corruption. London: Emerald.

Sikka, P. (2008). Enterprise culture and accountancy firms: New masters of the universe, accounting. Auditing and Accountability Journal, 21(2), 268-295.

Sikka, P., \& Willmott, H. (2010). The dark side of transfer pricing: Its role in tax avoidance and wealth retentiveness. Critical Perspectives on Accounting, 21(4), 342356.

Transparency International (2007). Persistent corruption in low-income countries requires global action. Berlin: Transparency International http://www. transparency.org/files/content/pressrelease/Presskit_engl_ALLinclFAQ_200907.pdf

UK Africa All Party Parliamentary Group (2006). The other side of the coin: The UK and corruption in Africa. London: House of Commons.

UK Department of Trade and Industry (1997). Guinness PLC. London: The Stationery Office.

United Nations Office on Drugs and Crime (2003). United Nations convention on corruption. Vienna: United Nations.

United States Department of Justice (2014, April). Hewlett-Packard Russia agrees to plead guilty to foreign bribery. Washington, DC: DOJ http://www.justice.gov/ opa/pr/2014/April/14-crm-358.html

United States Department of State (2011, May). Consent agreement: In the matter of BAE systems plc. Washington, DC: US Department of State http://www.pmddtc. state.gov/compliance/consent_agreements/pdf/BAES_CA.pdf 
United States District Court for the District of Columbia (2010). United State of America v BAE plc - VIOLATION: Title 18, United States Code, Section 371 (Conspiracy). http://www.justice.gov/criminal/pr/documents/03-01-10BAE-information.pdf

United States Securities and Exchange Commission (2014). In the matter of Hewlett-Packard Company: Order instituting cease-and desist proceedings pursuant to Section 21c of the Securities Exchange Act of 1934, making findings, and imposing a cease and desist order. Washington, DC: SEC https://www.sec.gov/litigation/ admin/2014/34-71916.pdf

Woolf Committee (2008). The Woolf committee report. London: BAE http://www.baesystems.com/our-company-rzz/corporate-responsibility/ working-responsibly/meeting-high-ethical-standards/our-response-to-the-woolf-committee-recommendations?_afrLoop=548851468488000 \&_afrWindowMode=0\&_afrWindowId=null\#!\%40\%40\%3F_afrWindowId\%3Dnull\%26_afrLoop\%3D548851468488000\%26_afrWindowMode\%3D0\%26_adf. ctrl-state\%3Ddzp8pwufr_71). 